\section{Seasonal expressions of prolactin, prolactin receptor and STAT5 in the scented glands of the male muskrats (Ondatra zibethicus)}

\author{
Wenqian Xie, Hong Liu, Qian Liu, \\ Qiong Gao, Fuli Gao, Yingying Han, \\ Zhengrong Yuan, Haolin Zhang, \\ Qiang Weng
}

Laboratory of Animal Physiology, College of Biological Sciences and Technology, Beijing Forestry University, Beijing, China

\begin{abstract}
Prolactin (PRL) production in mammals has been demonstrated in extrapituitary gland, which can activate autocrine/ paracrine signaling pathways to regulate physiological activity. In the current study, we characterized the gene expression profiles of PRL, prolactin receptor (PRLR) and signal transducers and activators of transcription 5 (STAT5) in the scented glandular tissues of the muskrats, to further elucidate the relationship between PRL and the scented glandular functions of the muskrats. The weight and volume of the scented glands in the breeding season were significantly higher than those of the non-breeding season. Immunohistochemical data showed that PRL, PRLR and STAT5/phospho-STAT5 (pSTAT5) were found in the glandular and epithelial cells of the scented glands in both seasons. Furthermore, we found that PRL, PRLR and STAT5 had higher immunoreactivities in the scented glands during the breeding season when compared to those of the non-breeding season. In parallel, the gene expressions of PRL, PRLR and STAT5 were significantly higher in the scented glands during the breeding season than those of the non-breeding season. The concentrations of PRL in scented glandular tissues and sera were measured by enzymelinked immunosorbent assay (ELISA), and their levels were both notably higher in the breeding season than those of the nonbreeding season. These findings suggested that the scented glands of the muskrats were capable of extrapituitary synthesis of PRL, which might attribute PRL a specific function to an endocrine or autocrine/paracrine mediator.
\end{abstract}

\section{Introduction}

In all vertebrates, prolactin (PRL) is a 23-kDa polypeptide hormone that is synthesized and stored by lactotroph cells in the anterior pituitary gland, and regulates multiple biological functions via endocrine signaling. ${ }^{1-3}$ The numerous different biological functions of PRL are mediated by the prolactin receptor (PRLR), which is a single membrane-bound protein that belongs to class I of the cytokine receptor superfamily. 2,4 There are three major PRLR isoforms described in rats are the long, intermediate, and short isoforms. ${ }^{3,5}$ The short and long forms differ from each other in the length of their cytoplasmic domain resulting from alternative splicing of a single primary transcript. Generally, the most abundant PRLR is the long isoform, whereas other intermediate and short forms also exist in mammals. All three types of PRLR are devoid of any intrinsic enzymatic activity, the first intracellular event in PRLR signaling is Janus Kinase-2 (JAK2) activation. ${ }^{6,7}$ It is the most common that the phosphorylated transcription factors activated by JAK 2 that belong to the family of signal transducers and activators of transcription (STAT), STAT1, STAT3 and STAT5 are the central transducer molecules of the signal transduction pathways initiated by PRLR activation. Of the STAT1, STAT3 and STAT5 proteins, STAT5 is identified as the most important transducer of the long and intermediate isoforms of the PRLR, whereas few amounts of phosphorylated STAT1 and STAT3 are detected. ${ }^{7}$ After activation by PRL, STAT5 recruits transcription factors of different signaling pathways leading to cell growth and differentiation. ${ }^{8}$

In a broad sense, when secreted into the circulation, PRL binds to the PRLR and activates JAK2-STAT5 signaling, which modulates a wide variety of physiological processes, including lactation, metabolism, immune responses and reproduction. PRLnull mice are unable to lactate due to a failure of lobuloalveolar differentiation of the mammary epithelium, similarly to PRLRnull and STAT5a-conventional knockout mice. ${ }^{9-11}$ The expressions of PRLR have been discovered in many nonclassical endocrine organs, such as skins, testes, prostates and reproductive accessory tissues. ${ }^{12-16}$ The almost ubiquitous presence of PRLR in multiple extrapituitary sites of PRL production implicates that some of these actions reflect local autocrine and paracrine roles of extrapituitary PRL. ${ }^{17}$ Autocrine and paracrine actions of PRL within the reproductive system are not only known to complement the endocrine actions of pituitary PRL in reproductive functions but also provide causal mechanisms for the
Correspondence: Qiang Weng, Laboratory of Animal Physiology, College of Biological Sciences and Biotechnology, Beijing Forestry University, Beijing 100083, China.

Tel. +86.10.6233.8682.

E-mail: qiangweng@bjfu.edu.cn

Haolin Zhang, Laboratory of Animal Physiology, College of Biological Sciences and Biotechnology, Beijing Forestry University, Beijing 100083, China.

Tel.: +86.10.6233.8682.

E-mail: haolinzhang@bjfu.edu.cn

Key words: Muskrat; prolactin; prolactin receptor; scented glands; STAT5.

Contributions: WX, HL, QL, QG, participated in sample collection, performing the experiments, analyzing the data and drafting the manuscript; HZ, FG, QW, assisted with all experiments and helped revising the manuscript; YH, ZY, QW, designed, supervised the study, and revised manuscript. All authors read and approved the final version.

Conflict of interest: The authors declare that they have no competing interests.

Acknowledgments: This research work is supported by National Natural Science Foundation of China (31872320, 21806010) and Beijing Natural Science Foundation (8182039) and Young Scientist Start-up funding of Beijing Forestry University (BLX201714).

Received for publication: 4 November 2018. Accepted for publication: 19 December 2018.

This work is licensed under a Creative Commons Attribution-NonCommercial 4.0 International License (CC BY-NC 4.0).

CC Copyright W. Xie, et al., 2019

Licensee PAGEPress, Italy

European Journal of Histochemistry 2019; 63:2991 doi:10.4081/ejh.2019.2991

induction of reproductive behavior. ${ }^{18}$ Recent studies in mice have suggested that circulating PRL is also detected in males, and it is found at lower levels than in females. ${ }^{12,19}$ The presence and abundance of PRL in the prostate, has provided a novel perspective on roles of PRL in the normal development, growth and function of the male reproductive physiology. ${ }^{20}$ Similarly, the finding of PRL and its receptor generally suggest that PRL positively modulates testicular functions in several ways. ${ }^{21}$ However, autocrine and paracrine mechanisms of PRL in male reproductive system remain unclear.

The muskrat (Ondatra zibethicus) is a kind of medium-sized, semi-aquatic rodent natively living in Canada, the United States and some parts of northern Mexico, later introduced in China. ${ }^{22}$ The muskrat has pre- 
cious medicinal and economic values because of its meat, fur and musk. Especially the musk, it is a widely-used and costly ingredient in traditional Chinese medicine and as a raw material for making high-end perfumes. ${ }^{23}$ The muskrat is a seasonal breeder with sexually active period of 8 months from March to October. The muskrat has a pair of the scented glands near its tail that give off a musky odor to attract females. During the breeding period, the male muskrat is willing to mate and produces mature spermatozoa, meanwhile, the scented glands secrete aromatic substance. $^{24,25}$ Previously, we observed that androgen receptor (AR), estrogen receptors (ER $\alpha$ and ER $\beta$ ), P450c17, 5-reductase type 2 and P450arom were present in the scented glandular tissues of the muskrats, which indicated the scented glands were the direct target organs for sex steroid hormones and its important autocrine/paracrine regulatory role in the scented glands of the muskrats. ${ }^{23,25-27}$ In the current study, we investigate the immunolocalizations and expression levels of PRL, PRLR and STAT5 as well as the concentrations of PRL in the scented glandular tissues during the breeding and non-breeding seasons, to elucidate the relationship between PRL and its receptor and the scented glandular functions of the muskrats.

\section{Materials and Methods}

\section{Animals}

Adult male muskrats were obtained in January $(n=6)$ and May $(n=6)$ from Xinji Muskrats Breeding Farm, Hebei Province, China. The muskrats were kept with a pattern of one male and one female in one enclosure. All experimental procedures were approved by the Animal Ethics Committee at the Experimental Center of Beijing Forestry University in accordance with the guidelines. After anesthesia with ether, all animals were euthanized by decapitation. Each pair of the scented glandular and testicular tissues was obtained from the male muskrats. One side of the scented glands and testes were immediately fixed overnight in 4\% paraformaldehyde (Sigma Chemical Co., St. Louis, MO, USA) in $0.05 \mathrm{M}$ PBS, pH 7.4 for histological and immunohistochemical observations; the other side were immediately stored at $-80^{\circ} \mathrm{C}$ until it was used for RNA isolation and PRL extraction.

\section{Histology}

The scented glands and testes were dehydrated in ethanol series and embedded in paraffin wax. Serial sections $(5 \mu \mathrm{m})$ were mounted on slides coated with poly-Llysine. Some sections were stained with hematoxylin-eosin (H\&E) for observations of general histology. The rest of the sections were processed for immunohistochemistry. The number of glandular cells in the muskrat scented glands was assessed with NIH ImageJ software, with the method described by Grishagin. ${ }^{28}$ Briefly, the histological photos were loaded in the ImageJ software and converted into 16-bit grayscale, followed by a threshold adjustment to distinguish cells from background. Finally, the cells were automatically identified by an appropriate particle feature.

\section{Immunohistochemistry}

Briefly, serial sections of the scented glandular tissues were incubated with $10 \%$ normal goat serum to reduce background staining and then incubated with primary rabbit polyclonal antibodies (1:200 dilutions) against PRL (bs-0508R) (Bioss Antibodies, Beijing, China), PRLR (bs6445R) (Bioss Antibodies, Beijing, China), STAT5 (bs-1142R) (Bioss Antibodies), phospho-STAT5 (Ser725/730, AF3304) (Affinity Biosciences, OH, USA) for $12 \mathrm{~h}$ under $4^{\circ} \mathrm{C}$. The sections were then incubated with a secondary antibody, goat anti-rabbit IgG conjugated with biotin and peroxidase with avidin, using rabbit ExtrAvidin Peroxidase staining Kit (Sigma Chemical Co., St. Louis, MO, USA), followed by visualizing with $20 \mathrm{mg} \mathrm{3,3-diaminobenzi-}$ dine (Wako, Tokyo, Japan) solution in 100 $\mathrm{mL}$ of $0.05 \mathrm{M}$ Tris-HCl buffer, $\mathrm{pH}$ 7.6, plus $17 \mu \mathrm{L} \mathrm{H}_{2} \mathrm{O}_{2}$. The control sections were treated with normal rabbit IgG (c-0006, Bioss Antibodies) at 1:2000 dilutions instead of the primary antibody. Finally, the reacted sections were counterstained with haematoxylin solution. The immunostained slides were examined using a photomicroscope (BX51, Olympus, Tokyo, Japan). The immunohistochemical staining was determined as positive $(+)$, strong positive $(++)$, very strong positive $(+++)$, and negative $(-)$. Staining that was weak but higher than control was set as positive $(+)$; the highest intensity staining was set as very strong positive $(+++)$; staining intensity between + and +++ was set as strong positive $(++)$.

\section{Total RNA isolation}

Total RNA from each sample was extracted using Trizol Reagent (Invitrogen Co., Carlsbad, CA, USA). Approximately $0.1 \mathrm{~g}$ of the scented glandular tissues were thawed and immediately homogenized in $1 \mathrm{~mL}$ of Trizol Reagent by ultrasonic crusher. The homogenate was incubated for 5 min at room temperature to allow the complete dissociation of nucleoprotein complexes. After the addition of $0.2 \mathrm{~mL}$ of chloroform, the mixture was vigorously shaken for $15 \mathrm{~s}$ at room temperature and centrifuged at $12,000 \times \mathrm{g}$ for $20 \mathrm{~min}$ at $4{ }^{\circ} \mathrm{C}$. The aqueous phase was then transferred to a fresh tube, and an equal volume of isopropanol was added. Then the sample was kept for $10 \mathrm{~min}$ at room temperature. RNA was precipitated by centrifugation at 12,000 $\times \mathrm{g}$ for $20 \mathrm{~min}$ at $4^{\circ} \mathrm{C}$. The RNA pellet was washed twice with $70 \%$ ethanol, briefly dried under air, and dissolved in $50 \mu \mathrm{L}$ of diethylprocarbonate-treated water. The integrity of RNA was tested by gel electrophoresis and its concentration was measured with spectrophotometer.

\section{Quantitative real-time PCR}

The first-strand cDNA from total RNA was synthesized using StarScript II Firststrand cDNA Synthesis Mix (GenStar, Beijing, China). The $10 \mu \mathrm{L}$ of reaction mixture contained $1.5 \mu \mathrm{g}$ of total RNA, $0.5 \mu \mathrm{L}$ of Random Primer, $0.5 \mu \mathrm{L}$ of StarScript II RT Mix, $5 \mu \mathrm{L}$ of $2 \times$ Reaction mix, $2.5 \mu \mathrm{L}$ of diethylprocarbonate- $\mathrm{ddH}_{2} \mathrm{O}$ according to the manufacturer's protocol. The cDNA was stored at $-20^{\circ} \mathrm{C}$. Primers used are listed in Table 1. The annealing temperature used for all primers was $60^{\circ} \mathrm{C}$. The PCR reactions were carried out in a $10 \mu \mathrm{L}$ volume using FastStart DNA MasterPlast SYBR green Kit (Roche Molecular System Inc., Basel, Switzerland). The PCR conditions were performed in ABI PRISM 7500 Fast Real-Time $7500 \quad$ System (Applied

Table 1. Oligonucleotide primers used for quantitative real-time PCR.

$\begin{array}{llc}\text { Gene } & \text { Primer sequence } & \text { Production length (bp) } \\ \text { Prl } & \text { F: GGTCATCAATGACTGCCCCA } & 150 \\ & \text { R: CTCGAGGACTGCACCAAACT } & 135 \\ \text { Prlr } & \text { F: CATCTGCTGGAGAAGGCAA } & \\ & \text { R: CATTAGCCGCTCGTCCTCAT } & 125 \\ \text { Stat5 } & \text { F: AAAGAATCAAGCGTGCTGACAGA } & \\ & \text { R: GGACAGGGTCTTCACCTGGAA } & 223 \\ \text { Actb } & \text { F: GACTCGTCGTACTCCTGCTT } & \\ & \text { R: AAGACCTCTATGCCACACC } & \end{array}$


Biosystems, Foster City, CA, USA) as described below: $10 \mathrm{~min}$ at $95^{\circ} \mathrm{C}$, followed by 40 cycles of $30 \mathrm{~s}$ at $95^{\circ} \mathrm{C}, 30 \mathrm{~s}$ at $60^{\circ} \mathrm{C}$ and $30 \mathrm{~s}$ at $72^{\circ} \mathrm{C}$. The melting curves were also performed to test the homogeneity of the PCR products by increasing the temperature progressively to $95^{\circ} \mathrm{C}$, then decreasing it to $65^{\circ} \mathrm{C}$ for $60 \mathrm{~s}$ and increasing it again to $95^{\circ} \mathrm{C}$. The expression level of each target mRNA relative to $A c t b$ mRNA was determined using the $2^{-\Delta \Delta \mathrm{Ct}}$ method.

\section{Hormone measurement}

The frozen portion of the scented glandular tissues of the male muskrats were lysed in a homogenizer containing PBS and the homogenates were centrifuged at 12,000 $\times \mathrm{g}$ for $5 \mathrm{~min}$ at $4^{\circ} \mathrm{C}$. Blood samples were also centrifuged for $15 \mathrm{~min}$ at $1000 \times \mathrm{g}$ at $4^{\circ} \mathrm{C}$. The supernatant of the homogenized tissue or plasma was collected and assayed immediately by ELISA Kit (Kit CSBE06881r for PRL, Cusabio Biotech Co., Ltd., Wuhan, China). In brief, $50 \mu \mathrm{L}$ per well of tissue samples, plasma samples or standard were added into the assay plate that were coated with goat-anti-rabbit IgG antibody. And then $50 \mu \mathrm{L}$ of HRP-conjugate were added to each well, followed by $50 \mu \mathrm{L}$ rabbit-anti-rat PRL antibody. The plate was mixed well and then incubated for $60 \mathrm{~min}$ at $37^{\circ} \mathrm{C}$. After aspirating and washing 3 times with wash buffer, the assay plate was colored and read using a microplate reader (PT 3502G, Beijing Potenov Technology Co., Ltd., Beijing, China) at $450 \mathrm{~nm}$ within 10 min. The detection limitation for PRL Kit is $0.125 \mathrm{ng} / \mathrm{mL}$. The intra-assay and interassay coefficient of variation for PRL was $4.7 \%$ and $8.8 \%$, respectively. The validation of ELISA Kit for the muskrats was checked by examining the parallelism between the standard curve and series diluted sample curve.

\section{Statistical analysis}

Statistical comparisons with the Student's $t$-test and correlation analysis were made using GraphPad Prism 7. A value of $\mathrm{P}<0.05$ was considered indication of statistical significance.

\section{Results}

\section{Histology}

Morphological and histological observations of the scented glands in the breeding and non-breeding seasons were performed, and distinct variations were observed in Figure 1 and Figure 2. The picture of the muskrat was shown in Figure 1a. The scented glands, situated at hypogastri- um and between the skin layer and muscle layer at the ventral base of the tail (Figure 1b). Relatively larger size of the scented glands in the breeding season than that of the non-breeding season was observed (Figure 1c). The average weight and volume of the scented glands in the breeding season were significantly higher than those of the non-breeding season (Figure $1 \mathrm{~d}, \mathrm{e}$ ). In addition, histological observations revealed three types of cells, including epithelial cells, glandular cells and interstitial cells (Figure $2 \mathrm{a}, \mathrm{b}$ ). H\&E staining of the muskrat testes also revealed that all types of germ cells were shown in the breeding season, while only spermatogonia and primary spermatocytes could be identified in the nonbreeding season (Figure $2 \mathrm{c}, \mathrm{d}$ ). The density of glandular cell nuclei in the breeding season was notably higher than those in the non-breeding season, as shown in Table 2.

\section{Immunohistochemistry}

Immunolocalizations for PRL, PRLR, STAT5 and pSTAT5 were present in the scented glands of the muskrats during the breeding and non-breeding seasons, respectively (Figure 3 ). The positive staining of PRL and PRLR were observed intensely in the cytoplasm of the epithelial and glandular cells in both the breeding and non-breeding seasons, while no immunostaining was observed in the interstitial cells (Figure 3 $a, b, e, f)$. The positive signal of STAT5 was localized at the cytoplasm of the glandular and epithelial cells in the breeding season, respectively (Figure 3i), however, the immunostaining was only weakly detected in the cytoplasm of the epithelial and glandular cells in the non-breeding season, whereas no positive signal existed in the interstitial cells (Figure 3j). The positive signal of pSTAT5 was detected in the cyto-

Table 2. Mean cell density of glandular cell nuclei $\pm S E M / \mathrm{mm}^{2}$ in the scented gland of the muskrat during the breeding and non-breeding seasons.

\begin{tabular}{lc} 
Period & Glandular cell number $(\times 10)$ \\
Breeding & $97 \pm 4^{*}$ \\
Non-breeding & $74 \pm 5$ \\
\hline${ }^{*}<0.05$ &
\end{tabular}

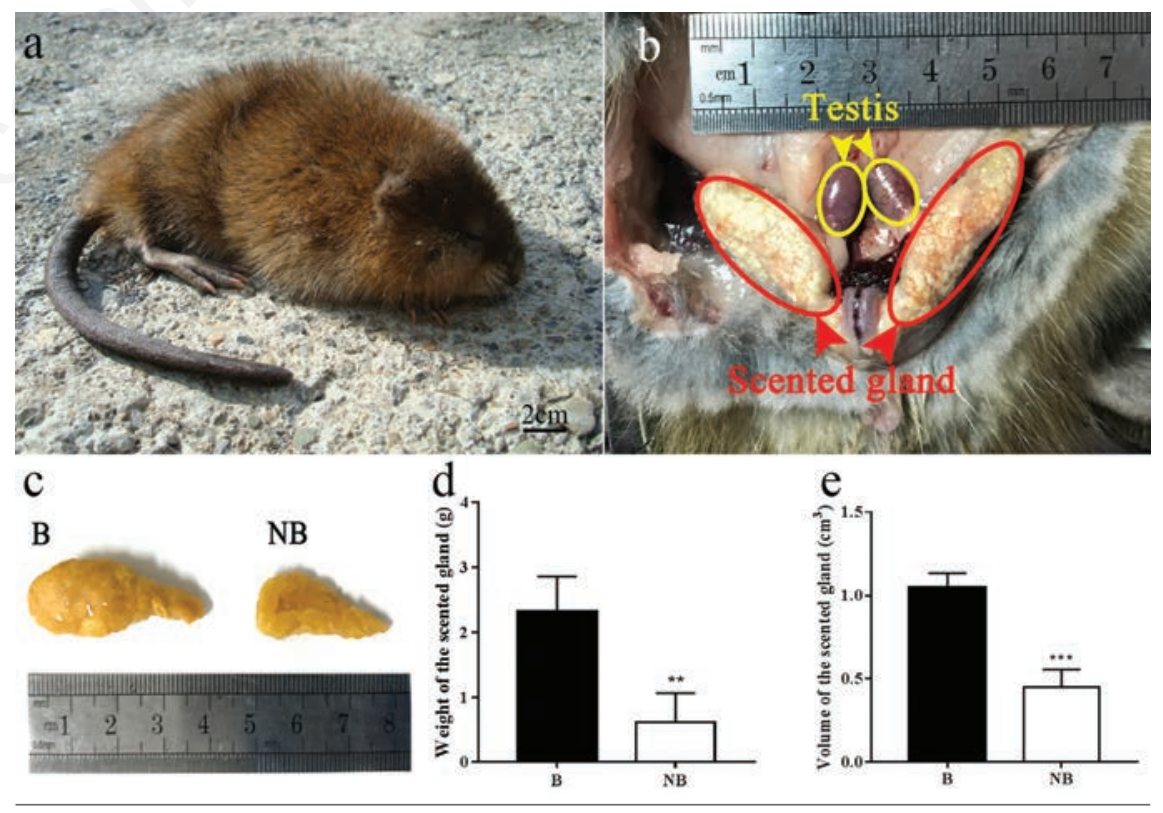

Figure 1. Anatomic localization and morphology of the muskrats scented glands. a) The whole of the muskrat. b) Anatomic localization and morphology of the scented glands. c) The morphology of the scented glands after fixation. d) The average weight of the scented glands in the breeding and non-breeding seasons. e) The average volume of the scented glands in the breeding and non-breeding seasons. B, breeding season; NB, nonbreeding season. The error bars represent means ${ } \mathrm{SEM}(\mathrm{n}=6$, each period $) .{ }^{* *} \mathrm{P}<0.01$; *** $\mathbf{P}<0.001$. 
plasm of the epithelial and glandular cells in both breeding and non-breeding seasons, while no immunostaining was detected in the interstitial cells (Figure $3 \mathrm{~m}, \mathrm{o}$ ). Moreover, positive controls were set by using sections of mammary gland of the muskrats, PRL, PRLR, STAT5 and pSTAT5 were expressed in the mammary epithelial cells (Figure 3 c,g,k,p). No immunohistochemical signal was found in the negative controls (Figure 3 d,h,l,q). All staining images were quantified and all the positive signals were stronger in the breeding season, which were summarized in Table 3.

\section{Real-time PCR}

The mRNA expression levels of Prl, Prlr and Stat 5 were compared between the breeding and non-breeding seasons in the scented glands of the muskrats (Figure 4). The level of $\mathrm{Prl}$ transcripts in the scented glands of the muskrats decreased significantly from the breeding season to the nonbreeding season (Figure 4a). Similarly, the expressions of Prlr and Stat5 were significantly higher in the scented glands of the breeding season, and markedly reduced in the scented glands of the non-breeding season (Figure 4 b,c).

\section{Correlation analysis}

The linear correlation and scatter diagram of relative expressions of Prl, Prlr and Stat 5 and weight of the scented glands of the muskrats during the breeding and nonbreeding seasons were shown in Figure 5. Scatter diagram of relative expression of Prlr and Stat5 and weight of the scented glands were shown (Figure $5 \mathrm{~b}, \mathrm{c}$ ). The relative expressions of $\mathrm{Prl}, \mathrm{Prlr}$ were positively correlated with the weight of the scented glands of the muskrats $(r=0.9795 ; r=$ 0.9163; $\mathrm{P}<0.01$ ) (Figure $5 \mathrm{a}, \mathrm{b})$. Similarly, the positive correlation was found between the relative expression of Stat 5 and the scented glandular weight $(\mathrm{r}=0.83 ; \mathrm{P}<0.05)$ (Figure 5c).

\section{Hormone assay}

The concentrations of PRL in the scented glands and sera of the muskrats during breeding and non-breeding seasons were shown in Figure 6. The PRL level was significantly higher in the breeding season $(0.811 \pm 0.176 \mathrm{ng} / \mathrm{g})$ than that in the nonbreeding season (0.379 $\pm 0.022 \mathrm{ng} / \mathrm{g})$; $\mathrm{P}<0.01$ (Figure 6a). Similar trend was also observed in the sera, as the PRL level decreased from $5.297 \pm 0.120 \mathrm{ng} / \mathrm{ml}$ in the breeding season to $3.512 \pm 0.103 \mathrm{ng} / \mathrm{mL}$ in the non-breeding season; $\mathrm{P}<0.01$ (Figure $6 b)$.

\section{Discussion}

The present study demonstrated that the expression levels of PRL mRNA and the concentrations of PRL in the scented glandular tissues were both notably higher in the breeding season, indicative of local PRL synthesis in the scented glands of the muskrats. In addition, the increases in weight and size of the scented glands were positively correlated with the changes in the expression levels of PRLR and STAT5/pSTAT5 during the breeding season when compared to those of the non-breeding season. These findings suggested that the scented glands of the muskrats were capable of locally synthesizing PRL, and
PRL might play an important regulatory role in the scented glandular function via endocrine or autocrine/paracrine manners.

The morphological characteristics of affiliated gonads usually show annual reproductive cycle changes with reproductive hormones. ${ }^{29}$ For instance, in viscacha, changes in the structure of the epididymis were likely due to a decrease in testosterone levels during the short period of gonadal regression. ${ }^{29}$ In wild Daurian ground squirrels, the relationship between the changes in size and weight of the gonad and the hormone levels indicated morphological changes of attached reproductive organs were usually accompanied by changes in reproductive hormone..$^{30-33}$ In horses,

Table 3. Immunolocalizations of PRL, PRLR, STAT5 and pSTAT5 in the scented glands of the muskrats during the breeding and non-breeding season.

\begin{tabular}{|c|c|c|c|c|c|c|}
\hline & $\begin{array}{c}\text { Glandu } \\
\text { B }\end{array}$ & NB & $\begin{array}{c}\text { Interstitial cell } \\
\text { B }\end{array}$ & $\begin{array}{l}\text { Epithelial cell } \\
\text { NB }\end{array}$ & B & NB \\
\hline PRL & +++ & + & - & - & +++ & + \\
\hline PRLR & +++ & + & - & - & ++ & + \\
\hline STAT5 & +++ & + & - & - & +++ & + \\
\hline pSTAT5 & +++ & + & - & - & ++ & + \\
\hline
\end{tabular}

EC, epithelial cells; GC, glandular cell; IC, interstitial cells; B, breeding season; NB, non-breeding season; -, negative staining; +, positive staining; ++ , strong positive staining; +++ , very strong positive staining.

B
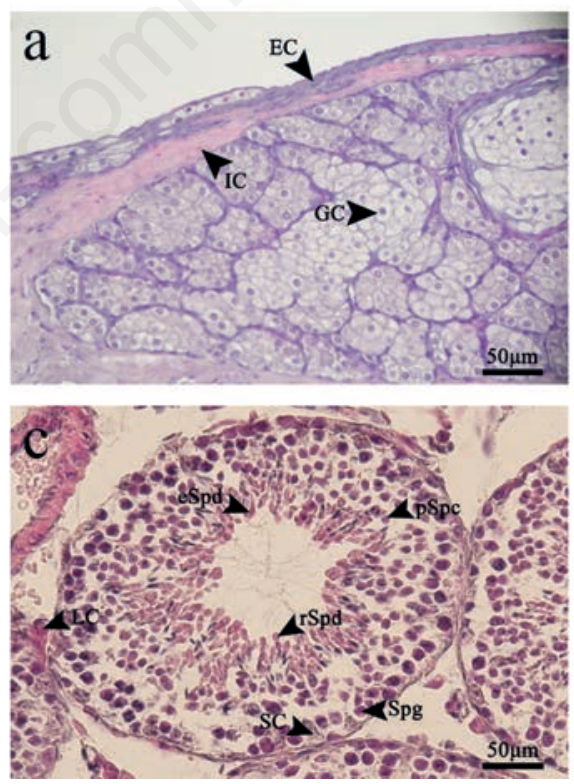

NB
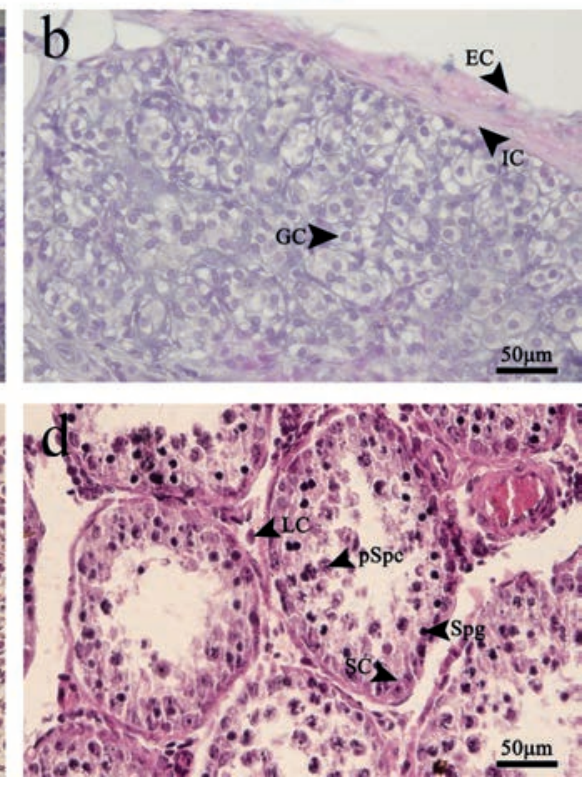

Figure 2. Histological structure of muskrats scented glands and testes by hematoxylineosin (H\&E) a,b) Histological observation of the scented glands in the breeding season (a) and the non-breeding season (b). c,d) Histological observations of the testes in the breeding season (c) and the non-breeding season (d). Scale bars: $50 \mu \mathrm{m}$. B, breeding season; NB, non-breeding season; GC, glandular cell; EC, epithelial cell; IC, interstitial cell; LC, Leydig cells; SC, Sertoli cells; Spg, spermatogonia; pSpc, primary spermatocytes; rSpd, round spermatids; eSpd, elongated spermatids. 
extended light treatment increased the circulating PRL concentration, resulting in the active gonadal function, growth promotion and better hair coat condition. ${ }^{34}$ In this study, morphological changes in the scented glands of the muskrats were found throughout the annual reproductive cycle. In the breeding season, the weight and size of the scented glands were significantly increased, which established the basis for the secretion and storage of the scented glands and also was consisted with observations obtained previously in our laboratory. ${ }^{23,25,35,36}$ Correspondingly, the increased PRL levels in the circulation and the scented gland with the long-day period as well as the more glandular cells number and higher density of the epithelial cells were found during the breeding season, which implied that the increased circulating and/or local PRL in the scented glands might be involved in the enlarged scented gland and musk secretion during the breeding season.

It is well known that PRL is secreted from the pituitary, however, PRL and its receptor were found in a series of peripheral organs, indicating that there were autocrine or paracrine actions of PRL complementing the endocrine actions of pituitary PRL in multiple peripheral organs..$^{3,17,37}$ The local production of PRL has been reported in the peripheral organs, such as placentae, ${ }^{38}$ skins ${ }^{39}{ }^{39}$ ovaries, ${ }^{40}$ testes and mammary glands. ${ }^{20,41,42}$ In African and Asian ele- phants, immunoreactive (ir)-PRL was detected in placental homogenates and immunolocalization was detected in trophoblasts, indicating that the placenta is the source of ir-PRL during pregnancy in elephants. ${ }^{38}$ In mice, PRL has been reported to stimulate hair growth in seasonally independent hair cycles, and acted as an autocrine hair growth modulator with catagen promoting functions. ${ }^{39}$ In the current study, PRL concentration and mRNA levels in the scented glandular tissues were detected to be higher in the breeding period, which suggested the scented glands of the muskrats had ability to locally synthesize PRL. Although the presence of PRLR isoforms in the scented gland were not distin-

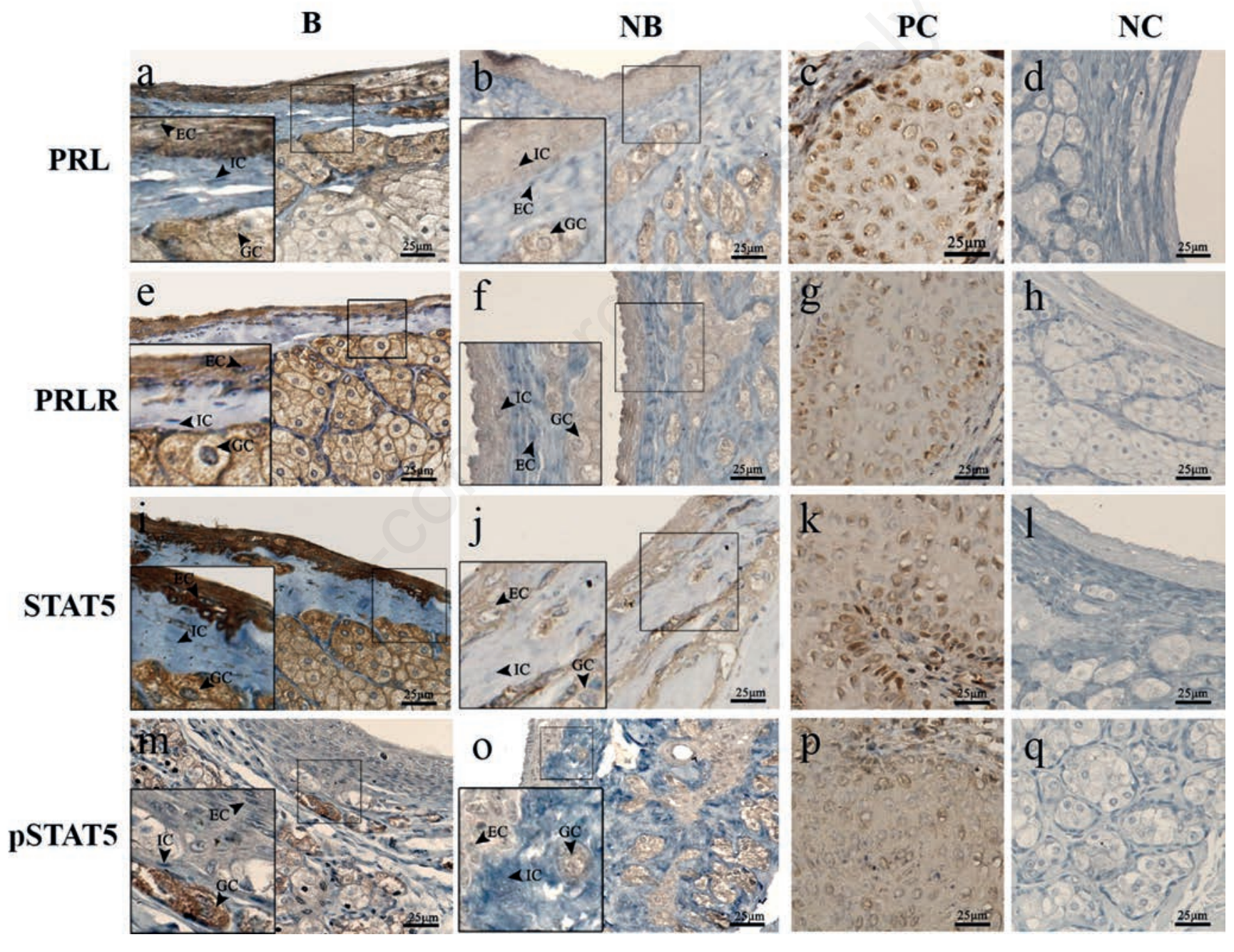

Figure 3. Seasonal immunolocalization of PRL, PRLR, STAT5 and pSTAT5 in the scented glands of the muskrats. Black arrows indicate the three cell types: glandular cells, epithelial cells and interstitial cells. The first column (a,e,i,m) represents staining in the breeding season. The second column $(b, f, j, o)$ represent staining in the non-breeding season. The third $(c, g, k, p)$ and fourth $(d, h, 1, q)$ columns represent staining in the positive and negative control, respectively. a,b) Immunolocalization of PRL in the scented glands. e,f) Immunolocalization of PRLR in the scented glands. $\mathrm{i}, \mathrm{j}$ ) Immunolocalization of STAT5 in the scented glands. m,o) Immunolocalization of pSTAT5 in the scented glands. PRL, PRLR, STAT5 and pSTAT5 detected in the mammary glands were used as a positive control $(\mathbf{c}, \mathbf{g}, \mathbf{k}, \mathbf{p})$. Negative control sections were treated with normal rabbit serum instead of primary antisera (d,h,l,q). B, breeding season; NB, non-breeding season; PC, positive control; NC, negative control; GC, glandular cell; EC, epithelial cell; IC, interstitial cell. Scale bars: $25 \mu \mathrm{m}$. 
guished, the data at protein and mRNA levels clearly showed that PRLR was presented in the scented glands of muskrats, and therefore PRL might affect development and functions of the scented glands via autocrine/paracrine manners. The local PRL exerts various functions in the peripheral tissues. In human prostate, PRL had a characteristic effect on the prostatic morphology and it increased DNA synthesis in human prostatic tissue in organ culture. ${ }^{43}$ The present data showed the increased PRL expres- sions (protein/mRNA) were found together with the increased cell number of glandular and epithelial cells, and the locally expressed PRL were correlated to the weight of the scented glands, which suggested the local PRL might affect cell proliferation and scented glandular morphology. The lines of evidence had indicated that PRL acted at several levels of male reproduction in many mammals, playing a role in steroidogenesis and gametogenesis in the testis. ${ }^{18,19,42}$ Moreover, PRL originated from the testes could affect spermatogenesis via influencing the steroidogenesis. ${ }^{44}$ Interestingly, our previous studies demonstrated that AR, ERs and steroidogenic enzymes were expressed in the scented glands of the muskrats and showed higher expression levels in the breeding season, which caused higher organic concentrations of testosterone and estrogen respectively. ${ }^{23,26,27}$ Combining those data together, it indicated that the local PRL could possibly also influence steroidogenesis in the scent-
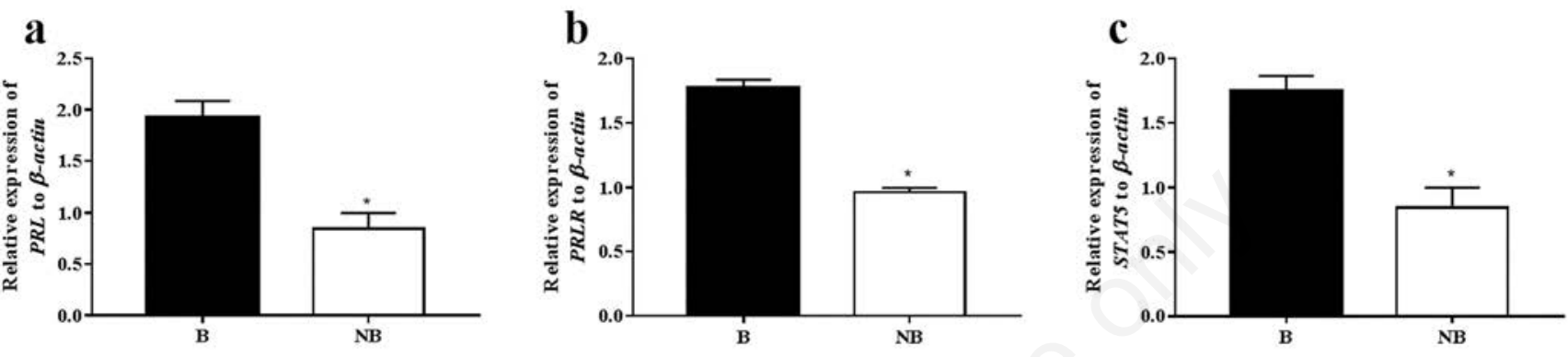

Figure 4. Seasonal mRNA expression of $\operatorname{Prl}(\mathrm{a}), \operatorname{Prlr}(\mathrm{b})$ and $\operatorname{Stat5}(\mathrm{c})$ in the scented glands. The error bars represent means \pm SEM (n $=3$, each period). $B$, breeding season; NB, non-breeding season. ${ }^{*} P<0.05$.

a

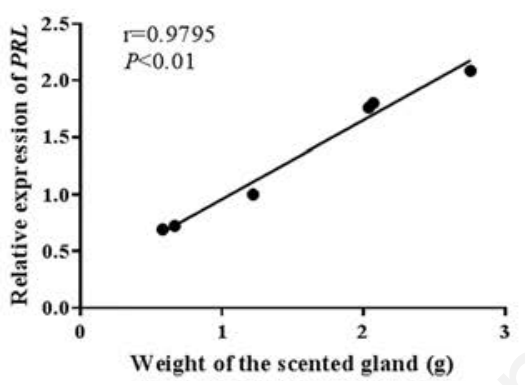

b

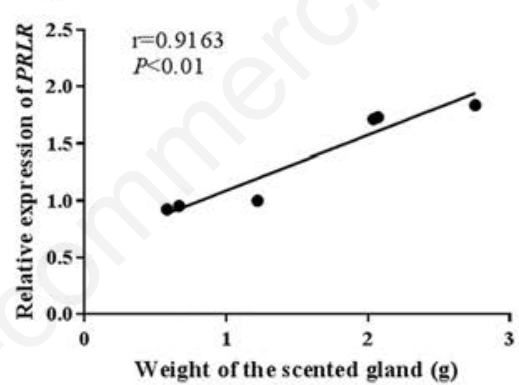

C

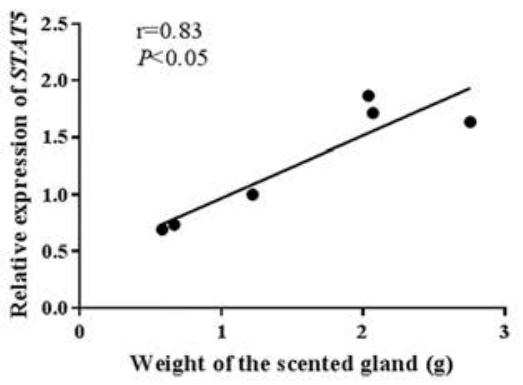

Figure 5. The linear correlation and scatter diagrams of relative expression of Prl, Prlr and Stat5 and weight of the scented glands of the muskrats. Each dot means the relative mRNA level and weight of the scented glands of six individual muskrats obtained in the breeding season $(n=3)$ and the non-breeding season $(n=3)$.

a

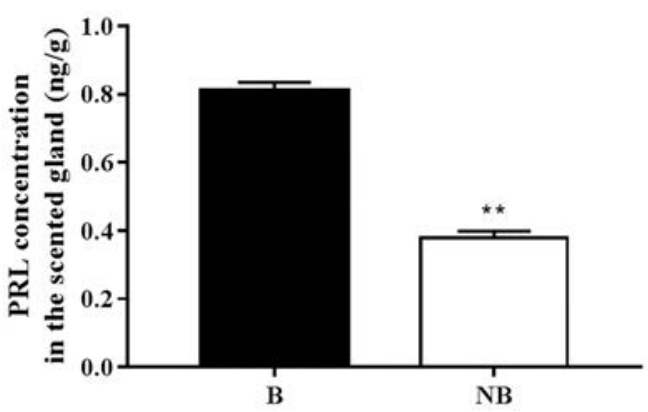

b

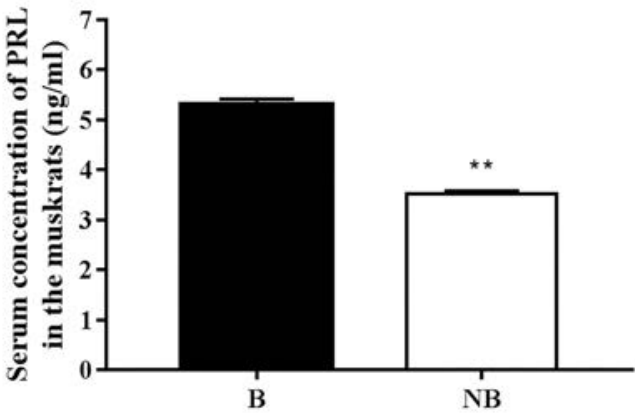

Figure 6. Seasonal PRL concentrations in the scented glands (a) and sera (b) of the muskrats. The error bars represent means \pm SEM $\left(\mathrm{n}=6\right.$, each period). $\mathrm{B}$, breeding season; $\mathrm{NB}$, non-breeding season. ${ }^{* *} \mathrm{P}<0.01$. 
ed glands of the muskrats and lead to the functional changes of scented glands during different seasons, which would be confirmed in the further study.

It is well established that PRL predominantly utilizes the STAT pathway to transduce its signal to activate PRLR to regulate more than 300 different biological functions in mammals. ${ }^{3}$ Numerous studies showed that STAT5 signaling pathway regulated by PRL played a predominant role in the development and differentiation of organs. The transcription factor STAT5 was well characterized as a critical transcription factor in the downstream of the PRLR signaling that mediates many PRL activities..$^{7,10,45}$ In human mammary epithelial cells, endogenous PRL interacts with PRLR-activated STAT5 to regulate mammary activities, such as mammopoiesis, lactogenesis and post-lactational regression. ${ }^{7}$ During pregnancy, the differentiation of mammary alveolar cells and milk-protein gene expression in female mice coincided with STAT5 phosphorylation, indicating that the activation of STAT5 was a critical step in the terminal differentiation of mammary secretory epithelial cells. ${ }^{8,46}$ In prostate epithelial cells, the increased activation of STAT5 regulated by autocrine/paracrine PRL was associated with more biologically aggressive behavior of prostate cancer. ${ }^{47,48}$ A large body of evidence supported the fact that STAT5 was the critical pathway that was activated by PRL in tissues, and that its inhibition interfered with some disease progression in experimental models. ${ }^{20,49,50}$ In this study, we investigated the seasonal expressions of PRLR/(p)STAT5 signaling pathway, and the results showed that PRLR and STAT5/pSTAT5 were localized in the epithelial cells and glandular cells. And furthermore, the mRNA levels of PRLR and STAT5 were correlated with their immunostaining results. Taken together, those data suggested that the PRLR/STAT5 signaling activated by PRL might be involved in maintaining and regulating the functions of the scented glands in the muskrats.

The present study demonstrated that PRL, PRLR and STAT5 were expressed in the scented glands of the muskrats and there was higher concentration of PRL in the scented glandular tissues during the breeding season. These findings suggested that PRL might affect functions of the scented glands via an autocrine/paracrine mechanism by regulating the PRLR/STAT5 signaling pathway. The data provided here will greatly help in determination of the PRL/STAT5 signaling pathway in the scented glands of the muskrats, the animal model of choice for studying the function of male accessory glands with regulation of endocrine hormone.

\section{References}

1. Bachelot A, Binart N. Reproductive role of prolactin. Reproduction 2007;133: 361-9.

2. Ben-Jonathan N, LaPensee CR, LaPensee EW. What can we learn from rodents about prolactin in humans? Endocr Rev 2008;29:1-41.

3. Freeman ME, Kanyicska B, Lerant A, Nagy G. Prolactin: Structure, function, and regulation of secretion. Physiol Rev 2000;80:1523-631.

4. Bernichtein S, Touraine P, Goffin V. New concepts in prolactin biology. J Endocrinol 2010;206:1-11.

5. Bolefeysot C, Goffin V, Edery M, Binart N, Kelly PA. Prolactin (PRL) and its receptor: Actions, signal transduction pathways and phenotypes observed in PRL receptor knockout mice. Endocr Rev 1998;19:225-68.

6. Gao J, Hughes JP, Auperin B, Buteau H, Edery M, Zhuang $\mathrm{H}$, et al. Interactions among Janus kinases and the prolactin (PRL) receptor in the regulation of a PRL response element. Mol Endocrinol 1996;10:847-56.

7. Hughes K, Watson CJ. The spectrum of STAT functions in mammary gland development. JAKSTAT 2012;1:151-8.

8. Bridgewater RE, Streuli CH, Caswell PT. Extracellular matrix promotes clathrin-dependent endocytosis of prolactin and STAT5 activation in differentiating mammary epithelial cells. Sci Rep 2017;7:4572.

9. Horseman ND, Zhao W, Tanaka M, Nakashima K, Engle SJ, Smith F, et al. Defective mammopoiesis, but normal hematopoiesis, in mice with a targeted disruption of the prolactin gene. EMBO J 2014;16:6926-35.

10. Liu X, Robinson GW, Wagner KU, Garrett L, Wynshaw-Boris A, Hennighausen L. Stat5a is mandatory for adult mammary gland development and lactogenesis. Genes Dev 1997;11: 179-86.

11. Ormandy CJ, Camus A, Barra J, Damotte D, Lucas B, Buteau H, et al. Null mutation of the prolactin receptor gene produces multiple reproductive defects in the mouse. Genes Dev 1997;11:167-78.

12. Cao H, Wang L, Zhang S, Lu L, Sheng X, Han Y, et al. Seasonal Expression of Prolactin Receptor in the Scented Gland of Male Muskrat (Ondatra zibethicus). Sci Rep 2015;5:15036.

13. Foitzik K, Langan EA, Paus R. Prolactin and the skin: a dermatological perspective on an ancient pleiotropic peptide hormone. J Invest Dermatol 2009;129:1071-87.
14. Goffin V, Hoang DT, Bogorad RL, Nevalainen MT. Prolactin regulation of the prostate gland: a female player in a male game. Nat Rev Urol 2011;8:597607.

15. Hair WM, Gubbay O, Jabbour HN, Lincoln GA. Prolactin receptor expression in human testis and accessory tissues: localization and function. Mol Hum Reprod 2002;8:606-11.

16. Marano RJ, Ben-Jonathan N. Minireview: Extrapituitary prolactin: an update on the distribution, regulation, and functions. Mol Endocrinol 2014;28: 622-33.

17. Harvey S, Martinez-Moreno CG, Luna M, Aramburo C. Autocrine/paracrine roles of extrapituitary growth hormone and prolactin in health and disease: An overview. Gen Comp Endocrinol 2015; 220:103-11.

18. Gettler LT, McDade TW, Feranil AB, Kuzawa CW. Prolactin, fatherhood, and reproductive behavior in human males. Am J Phys Anthropol 2012;148:362-70.

19. Bartke A. Prolactin in the Male: 25 Years Later. J Androl 2004;25:661-6.

20. Goffin V. Prolactin receptor targeting in breast and prostate cancers: New insights into an old challenge. Pharmacol Ther 2017;179:111-26.

21. Ishida M, Yoshida M, Fukuta $S$, Uemura K, Iijima M, Horiguchi K, et al. Analysis of prolactin gene expression and cleaved prolactin variants in the mouse testis and spermatozoa. J Reprod Dev 2010;56:567-74.

22. Ma X, Zhang H, Weng J, Sheng X, Lu $\mathrm{L}, \mathrm{Hu} \mathrm{X}$, et al. Immunolocalization of inhibin/activin subunit proteins during the breeding season in testes and scented glands of muskrats (Ondatra zibethicus). J Vet Med Sci 2011;73:1199-205.

23. Han W, Xie W, Zhang Y, Zhang F, Zhang H, Han Y, et al. Seasonal expression of P450c17 and 5alpha-reductase-2 in the scented gland of male muskrats (Ondatra zibethicus). Gen Comp Endocrinol 2017;254:60-7.

24. Li Q, Weng J, Zhang H, Lu L, Ma X, Wang $Q$, et al. Immunohistochemical evidence: testicular and scented glandular androgen synthesis in muskrats (Ondatra zibethicus) during the breeding season. Eur J Histochem 2011;55: e32.

25. Lu L, Liu S, Li Q, Huang S, Bao L, Sheng $X$, et al. Seasonal expression of androgen receptor in scented gland of muskrat (Ondatra zibethicus). Gen Comp Endocrinol 2014;204:1-7.

26. Lu L, Zhang H, Na L, Ma X, Long T, $\mathrm{Xiao} \mathrm{H}$, et al. Immunolocalization of Androgen Receptor, Aromatase Cytochrome P450, Estrogen Receptor 
Alpha and Estrogen Receptor Beta Proteins during the Breeding Season in Scent Glands of Muskrats (Ondatra zibethicus). Zoolog Sci 2011;28:72732.

27. Zhang H, Lu L, Zhu M, Zhang F, Sheng $X$, Yuan Z, et al. Seasonal expression of P450arom and estrogen receptors in scented glands of muskrats (Ondatra zibethicus). Am J Physiol Regul Integr Comp Physiol 2017;312:380-7.

28. Grishagin IV. Automatic cell counting with ImageJ. Anal Biochem 2015;473: 63-5.

29. Aguilera-Merlo C, Munoz E, Dominguez S, Scardapane L, Piezzi R. Epididymis of viscacha (Lagostomus maximus maximus): morphological changes during the annual reproductive cycle. Anat Rec A Discov Mol Cell Evol Biol 2005;282:83-92.

30. Zhang Y, Wang Y, Huang C, Wang Y, Qi $\mathrm{H}$, Han Y, et al. Seasonal expression of $5 \alpha$-reductases and androgen receptor in the prostate gland of the wild ground squirrel (Spermophilus dauricus). Comp Biochem Physiol A Mol Integr Physiol 2018;226:11-6.

31. Wang Y, Wang Z, Yu W, Sheng X, Zhang H, Han Y, et al. Seasonal expressions of androgen receptor, estrogen receptors and cytochrome P450 aromatase in the uteri of the wild Daurian ground squirrels (Spermophilus dauricus). Eur J Histochem 2018;62:2889.

32. Li Q, Zhang F, Zhang S, Sheng X, Han $\mathrm{X}$, Weng $\mathrm{Q}$, et al. Seasonal expression of androgen receptor, aromatase, and estrogen receptor alpha and beta in the testis of the wild ground squirrel (Citellus dauricus Brandt). Eur J Histochem 2015;59:2456.

33. Zhang H, Wang Y, Zhang J, Wang L, Li Q, Sheng X, et al. Testicular expression of NGF, TrkA and p75 during seasonal spermatogenesis of the wild ground squirrel (Citellus dauricus Brandt). Eur J Histochem 2015;59:2522.

34. Korosue K, Murase H, Sato F, Ishimaru
M, Harada T, Watanabe G, et al. Successful induction of lactation in a barren Thoroughbred mare: growth of a foal raised on induced lactation and the corresponding maternal hormone profiles. J Vet Med Sci 2012;74:995-1002.

35. Zhang F, Liu Q, Wang Z, Xie W, Sheng $\mathrm{X}$, Zhang H, et al. Seasonal Expression of Oxytocin and Oxytocin Receptor in the Scented Gland of Male Muskrat (Ondatra zibethicus). Sci Rep 2017; 7:16627.

36. Zhang H, Zhang F, Zhu M, Wang J, Sheng X, Yuan Z, et al. Seasonal expressions of follicle-stimulating hormone receptor and luteinizing hormone receptor in the scented gland of the male muskrat (Ondatra zibethicus). Am J Physiol Regul Integr Comp Physiol 2017;312:569-74.

37. Weaver SR, Hernandez LL. Autocrineparacrine regulation of the mammary gland. J Dairy Sci 2016;99:842-53.

38. Yamamoto Y, Yamamoto T, Yuto N, Hildebrandt T B, Lueders I, Wibbelt G, et al. The Secretory Pattern and Source of Immunoreactive Prolactin in Pregnant African (Loxodonta africana) and Asian (Elephas maximus) Elephants. J Reprod Dev 2012;58:10511.

39. Langan EA, Foitzik-Lau K, Goffin V, Ramot Y, Paus R. Prolactin: an emerging force along the cutaneousendocrine axis. Trends Endocrinol Metab 2010;21:569-77.

40. Erdmann S, Ricken A, Merkwitz C, Struman I, Castino R, Hummitzsch K, et al. The expression of prolactin and its cathepsin D-mediated cleavage in the bovine corpus luteum vary with the estrous cycle. Am J Physiol Endocrinol Metab 2007;293:E1365-77.

41. Koizumi M, Horiguchi K, Tomita Y, Kato Y, Harigaya T. Prolactin gene expression in the mouse nipple. $\mathrm{J}$ Reprod Dev 2003;49:465-72.

42. Maeda K, Taniuchi S, Takahashi S, Takeuchi S. Pit-1w may regulate pro- lactin gene expression in mouse testis. Gen Comp Endocrinol 2012;178:180-4.

43. Sackmann-Sala L, Goffin V. Prolactininduced prostate tumorigenesis. Adv Exp Med Biol 2015;846:221-42.

44. Chandrashekar V, Bartke A. Influence of endogenous prolactin on the luteinizing hormone stimulation of testicular steroidogenesis and the role of prolactin in adult male rats. Steroid 1988;51:55976.

45. Yang X, Friedl A. A positive feedback loop between prolactin and STAT5 promotes angiogenesis. Adv Exp Med Biol 2015;846:265-80.

46. Miyoshi K, Shillingford JM, Smith GH, Grimm SL, Wagner KU, Oka T, et al. Signal transducer and activator of transcription (Stat) 5 controls the proliferation and differentiation of mammary alveolar epithelium. J Cell Biol 2001; 155:531-42.

47. Li H, Ahonen TJ, Alanen K, Xie J, Lebaron MJ, Pretlow TG, et al. Activation of signal transducer and activator of transcription 5 in human prostate cancer is associated with high histological grade. Cancer Res 2004;64:4774-82.

48. Agarwal N, Machiels JP, Suarez C, Lewis N, Higgins M, Wisinski K, et al. Phase I Study of the Prolactin Receptor Antagonist LFA102 in Metastatic Breast and Castration-Resistant Prostate Cancer. Oncologist 2016;21: 535-6.

49. Campo VAF, Persia FA, Hapon MB, Jahn GA. Hypothyroidism decreases JAK/STAT signaling pathway in lactating rat mammary gland. Mol Cell Endocrinol 2017;450:14-23.

50. Chen CC, Stairs DB, Boxer RB, Belka GK, Horseman ND, Alvarez JV, et al. Autocrine prolactin induced by the Pten-Akt pathway is required for lactation initiation and provides a direct link between the Akt and Stat5 pathways. Genes Dev 2012;26:2154-68. 